\title{
Ethics of Cardiac Transplantation in Hypoplastic Left Heart Syndrome
}

\author{
Alexander A. Kon \\ Published online: 25 April 2009 \\ (C) The Author(s) 2009. This article is published with open access at Springerlink.com
}

There has long been debate among experts in the care of infants born with hypoplastic left heart syndrome (HLHS) as to whether orthotopic heart transplantation or cardiac reconstruction is preferable as the primary approach $[1,15]$. Many centers now favor the reconstructive techniques (Norwood-type procedure); however, several centers continue to offer cardiac transplantation as a primary treatment. By the late 1990s, approximately $50 \%$ of children born with HLHS in the United States underwent cardiac reconstruction (studies indicate that approximately $35 \%$ of infants born with HLHS in the United States underwent cardiac reconstruction and survived to hospital discharge [9, 14] and that the rate of survival to discharge postreconstruction was approximately $70 \%[5,6,12,17,20,27,28]$, yielding a calculated value of $50 \%$ undergoing reconstruction), approximately $5 \%$ underwent cardiac transplantation (with an additional $2 \%$ dying while on the transplant waiting list) $[9,10,14]$, and the remaining patients (approximately 45\%) received palliative treatment (previously referred to as comfort care without surgery [18]). More recent data have not been published; therefore, the current percentages treated with each option is unknown.

In 2007, the American Heart Association Council on Cardiovascular Disease in the Young, the Councils on Clinical Cardiology, Cardiovascular Nursing, and Cardiovascular Surgery and Anesthesia, and the Quality of Care and Outcomes Research Interdisciplinary Working Group issued a consensus statement on indications for heart transplantation in children [7]. The authors of the consensus

\section{A. A. Kon $(\square)$}

Department of Pediatrics and the Program in Bioethics,

University of California Davis, 2516 Stockton Blvd,

Sacramento, CA 95817, USA

e-mail: aakon@ucdavis.edu statement noted that improved survival with cardiac reconstruction and the limited number of available donor hearts has "led to a decreased use of heart transplantation as primary therapy for HLHS" [7]; however, the decision whether to offer transplantation as primary therapy remains vested with the individual healthcare providers and their assessment of the best interests of their patient. Although it appears that most centers currently recommend reconstruction as the primary approach, a significant number continue to offer parents transplantation as one option for primary treatment [31]. Therefore, in many cases, infants with HLHS are treated primarily with cardiac transplantation based on the providers' and parents' beliefs that such treatment might represent even a slightly better option for that child over reconstruction. Although such decision making is consistent with the best interest standard, I will argue that when viewed from the perspective of the larger society, where issues of social justice must be considered, such allocation of a limited resource is inappropriate.

Approximately one-quarter of infants with HLHS who are listed for heart transplantation die before a heart becomes available, and the 5-year survival among those who undergo transplantation is approximately 70\% [10]. Based on these figures, the 5-year survival rate on an intention-to-treat basis is approximately $50 \%$ for transplantation. Further, because the 10-year graft survival is less than $50 \%[23,29]$, children who undergo heart transplantation will likely need another transplant every $10-15$ years. With such a high mortality rate among these and other children awaiting a donor heart, it is understandable that healthcare providers continue to look for expanded opportunities to increase the donor pool (e.g., using hearts from infants who died from cardiocirculatory causes [4]).

The other predominant surgical approach for these infants is the three-staged reconstructive technique 
consisting of the Norwood procedure in the neonatal period, followed by the Glenn procedure at 3-6 months of life, and, finally, by the Fontan procedure between 3 and 5 years of age. The 5-year survival for infants whose parents opt for cardiac reconstruction is reported to be approximately $70 \%[2,26]$, however some predict that the current survival is even greater than has been reported in the literature [30].

Regardless of the intervention chosen, survivors often experience unwanted sequellae. Infants with HLHS are at risk of abnormal brain development in utero, with approximately $25 \%$ of these infants being born with a head circumference in the lowest 10th percentile and an additional $25 \%$ having a head circumference in the 10th-20th percentile [25]. Further, survivors of both procedures are at risk of neurodevelopmental delay, with mean IQ scores of 86 (SD: 14; range: 57-115) [21]. Approximately 35\% of survivors have borderline mental retardation and an additional $18 \%$ have IQ scores below 70 regardless of surgical approach [19]. Survivors of both approaches also have significant limitations on their physical activity [13, 22, 24], require multiple admissions to the hospital and repeated procedures that might be frightening and painful for the child, and experience other negative physical and emotional effects. Studies comparing outcomes and sequellae for infants treated with these two approaches have demonstrated differences in the types of sequellae; however, there appears to be no clear benefit of one approach over the other [16, 21]. Therefore, although some experts continue to debate which approach is superior, it is clear that there is no compelling evidence that cardiac transplantation is necessarily superior to cardiac reconstruction.

Unlike newborns with HLHS, some infants have no other alternative. Children with end-stage cardiomyopathy, severe noncompaction syndrome, and other terminal heart defects cannot survive unless they receive a donor heart. On the whole, infants with HLHS can be equally well treated with either transplantation or reconstructive surgery; therefore, infants with other diagnoses who have no reasonable alternative should receive priority over infants with HLHS for donor hearts. Indeed, there are more than twice as many infants added to the heart waiting list annually compared to the number of new donors [7], and approximately 50 infants die annually while awaiting a donor heart [11]. Perhaps if society were to use this scarce resource more wisely, with priority given to non-HLHS infants and primarily employing cardiac reconstruction for HLHS, we could reduce the overall number of infants who die each year. In their recent report, the Denver group noted that nine infants met donation criteria; however, they were unable to donate due to lack of an appropriate recipient [4]. These data demonstrate that even if priority were given to non-HLHS infants, there might be instances in which a heart is made available to an infant with HLHS for primary treatment because no other suitable recipient is identified. Further, there might be cases when reconstructive surgery fails, and transplantation becomes the only reasonable rescue therapy for an infant with HLHS. In such cases, giving an infant with HLHS equal access to donor hearts would be reasonable.

The standard used in pediatric decision making is that of the child's best interest. Clinicians and parents are charged with using the best interest standard when making decisions for individual infants, although some have argued that parents might give some weight to the interests of other family members [3, 8]. Although data suggest similar burdens of sequellae for survivors regardless of the treatment employed, the types of sequellae differ significantly, with transplant recipients being at higher risk for hypertension, renal dysfunction, infections, and rejection and Norwood survivors being at higher risk of requiring anticongestive medications and interventional catheterizations [16]. Further, parents must weigh how other aspects of care might affect their family (e.g., many transplant centers require that families who live in remote areas relocate closer to the facility for a significant period of time posttransplantation). Individual practitioners and centers might also have biases favoring one approach over the other, and such biases might lead to greater experience, and therefore improved outcomes, with one approach. It might therefore be very appropriate for individual parents to judge that transplantation is the best option for their child.

Although such an approach to decision making is appropriate and expected for parents and healthcare providers, when viewing the healthcare system as a whole one must also consider issues of social justice. The United Network for Organ Sharing (UNOS) is charged with allocation of organs, and unlike clinicians caring for individual patients, UNOS must create policies that consider the interests of not only individual patients but also the interests of society as a whole. Therefore, UNOS might create policies that balance individual and societal interests and has done so in the past. Given that (1) for one group of infants (those with HLHS) there is no clear advantage for employing transplantation as the primary approach, (2) for another group of infants (e.g., those with end stage cardiomyopathy) transplantation is the only viable option, and (3) donor hearts are a scarce resource, the only tenable alternative is to give priority to infants who cannot be treated by any means other than transplantation. To be clear, however, such a decision should only be made on a broad basis with applicability nationally. UNOS would need to change policy regarding how organs are allocated. It would be inappropriate for individual practitioners to make such decisions independently because to do so would likely lead to significant disparities in healthcare provision 
and would violate the best interest standard as applied to individual patients.

Such a policy change might initially adversely affect a small number of infants (e.g., infants born at a transplantation center where the surgeons have little experience performing the Norwood procedure would likely have a lower survival rate when compared to the center's current, posttransplantation, survival rate); however, as centers gain experience with the Norwood procedure, such adverse effects would be significantly diminished. With approximately 50 deaths annually due to lack of available donor hearts, one would expect that the implementation of a policy giving priority to non-HLHS infants and encouraging the Norwood procedure as primary life-prolonging treatment for infants with HLHS would save many lives. Although the goal of parents and clinicians is, and should be, acting in the best interest of the individual child, as a society we must take a wider view.

Open Access This article is distributed under the terms of the Creative Commons Attribution Noncommercial License which permits any noncommercial use, distribution, and reproduction in any medium, provided the original author(s) and source are credited.

\section{References}

1. Bailey LL (2004) Transplantation is the best treatment for hypoplastic left heart syndrome. Cardiol Young 14(suppl 1):109-111

2. Ballweg JA, Dominguez TE, Ravishankar C, Kreutzer J, Marino BS, Bird GL, Gruber PJ, Wernovsky G, Gaynor JW, Nicolson SC, Spray TL, Tabbutt S (2007) A contemporary comparison of the effect of shunt type in hypoplastic left heart syndrome on the hemodynamics and outcome at stage 2 reconstruction. J Thorac Cardiovasc Surg 134(2):297-303

3. Bluebond-Langner M, DeCicco A, Belasco J (2005) Involving children with life-shortening illnesses in decisions about participation in clinical research: a proposal for shuttle diplomacy and negotiation. In: Kodish E (ed) Ethics and research with children: a case-based approach 2005. Oxford University Press, New York, pp 323-343

4. Boucek MM, Mashburn C, Dunn SM, Frizell R, Edwards L, Pietra B, Campbell D (2008) Pediatric heart transplantation after declaration of cardiocirculatory death. N Engl J Med 359(7):709-714

5. Bove EL (1998) Current status of staged reconstruction for hypoplastic left heart syndrome. Pediatr Cardiol 19(4):308

6. Bove EL (1999) Surgical treatment for hypoplastic left heart syndrome. Jpn J Thorac Cardiovasc Surg 47(2):47-56

7. Canter CE, Shaddy RE, Bernstein D, Hsu DT, Chrisant MR, Kirklin JK, Kanter KR, Higgins RS, Blume ED, Rosenthal DN, Boucek MM, Uzark KC, Friedman AH, Young JK (2007) Indications for heart transplantation in pediatric heart disease: a scientific statement from the American Heart Association council on cardiovascular disease in the young; the councils on clinical cardiology, cardiovascular nursing, and cardiovascular surgery and anesthesia; and the quality of care and outcomes research interdisciplinary working group. Circulation 115(5):658-676

8. Catlin A (2005) Thinking outside the box: prenatal care and the call for a prenatal advance directive. J Perinat Neonatal Nurs 19(2):169-176
9. Chang RK, Chen AY, Klitzner TS (2002) Clinical management of infants with hypoplastic left heart syndrome in the United States, 1988-1997. Pediatrics 110(2 Pt 1):292-298

10. Chrisant MR, Naftel DC, Drummond-Webb J, Chinnock R, Canter CE, Boucek MM, Boucek RJ, Hallowell SC, Kirklin JK, Morrow WR (2005) Fate of infants with hypoplastic left heart syndrome listed for cardiac transplantation: a multicenter study. $\mathrm{J}$ Heart Lung Transplant 24(5):576-582

11. Curfman GD, Morrissey S, Drazen JM (2008) Cardiac transplantation in infants. N Engl J Med 359(7):749-750

12. Drinkwater DC Jr, Aharon AS, Quisling SV, Dodd D, Reddy VS, Kavanaugh-McHugh A, Doyle T, Patel NR, Barr FE, Kambam JK, Graham TP, Chang PA (2001) Modified Norwood operation for hypoplastic left heart syndrome. Ann Thorac Surg 72(6):2081-2086 discussion 2087

13. Givertz MM, Hartley LH, Colucci WS (1997) Long-term sequential changes in exercise capacity and chronotropic responsiveness after cardiac transplantation. Circulation 96(1):232-237

14. Gutgesell HP, Gibson J (2002) Management of hypoplastic left heart syndrome in the 1990s. Am J Cardiol 89(7):842-846

15. Jacobs ML (2004) Staged reconstructive surgery: the most appropriate therapy for hypoplastic left heart syndrome. Cardiol Young 14(suppl 1):105-108

16. Jenkins PC, Flanagan MF, Jenkins KJ, Sargent JD, Canter CE, Chinnock RE, Vincent RN, O'Connor GT (2004) Morbidities in patients with hypoplastic left heart syndrome. Pediatr Cardiol 25(1):3-10

17. Kern JH, Hayes CJ, Michler RE, Gersony WM, Quaegebeur JM (1997) Survival and risk factor analysis for the Norwood procedure for hypoplastic left heart syndrome. Am J Cardiol 80(2):170-174

18. Kon AA (2008) Healthcare providers must offer palliative treatment to parents of neonates with hypoplastic left heart syndrome. Arch Pediatr Adolesc Med 162(9):844-848

19. Mahle WT, Clancy RR, Moss EM, Gerdes M, Jobes DR, Wernovsky G (2000) Neurodevelopmental outcome and lifestyle assessment in school-aged and adolescent children with hypoplastic left heart syndrome. Pediatrics 105(5):1082-1089

20. Mahle WT, Clancy RR, McGaurn SP, Goin JE, Clark BJ (2001) Impact of prenatal diagnosis on survival and early neurologic morbidity in neonates with the hypoplastic left heart syndrome. Pediatrics 107(6):1277-1282

21. Mahle WT, Visconti KJ, Freier MC, Kanne SM, Hamilton WG, Sharkey AM, Chinnock RE, Jenkins KJ, Isquith PK, Burns TG, Jenkins PC (2006) Relationship of surgical approach to neurodevelopmental outcomes in hypoplastic left heart syndrome. Pediatrics 117(1):e90-e97 Epub 2005 Dec 15

22. Mitchell ME, Ittenbach RF, Gaynor JW, Wernovsky G, Nicolson S, Spray TL (2006) Intermediate outcomes after the Fontan procedure in the current era. J Thorac Cardiovasc Surg 131(1):172-180

23. Morales DL, Dreyer WJ, Denfield SW, Heinle JS, McKenzie ED, Graves DE, Price JF, Towbin JA, Frazier OH, Cooley DA, Fraser CD $\mathrm{Jr}$ (2007) Over two decades of pediatric heart transplantation: how has survival changed? J Thorac Cardiovasc Surg 133(3):632-639 Epub 2007 Jan 29

24. Quigg R, Salyer J, Mohanty PK, Simpson P (1998) Impaired exercise capacity late after cardiac transplantation: influence of chronotropic incompetence, hypertension, and calcium channel blockers. Am Heart J 136(3):465-473

25. Shillingford AJ, Ittenbach RF, Marino BS, Rychik J, Clancy RR, Spray TL, Gaynor JW, Wernovsky G (2007) Aortic morphometry and microcephaly in hypoplastic left heart syndrome. Cardiol Young 17(2):189-195

26. Tabbutt S, Dominguez TE, Ravishankar C, Marino BS, Gruber PJ, Wernovsky G, Gaynor JW, Nicolson SC, Spray TL (2005) Outcomes after the stage I reconstruction comparing the right 
ventricular to pulmonary artery conduit with the modified Blalock Taussig shunt. Ann Thorac Surg 80(5):1582-1590

27. Tweddell JS, Hoffman GM, Mussatto KA, Fedderly RT, Berger S, Jaquiss RD, Ghanayem NS, Frisbee SJ, Litwin SB (2002) Improved survival of patients undergoing palliation of hypoplastic left heart syndrome: lessons learned from 115 consecutive patients. Circulation 106(12 Suppl 1):I82-I89

28. Tworetzky W, McElhinney DB, Reddy VM, Brook MM, Hanley FL, Silverman NH (2001) Improved surgical outcome after fetal diagnosis of hypoplastic left heart syndrome. Circulation 103(9): 1269-1273

29. Warshofsky MK, Dominguez M, Eisenberg MS, Wasserman HS, Sciacca R, Wang W, Simon AD, Morse JH, Schwartz A, Angles-
Cano E, Rabbani LE (2001) Elevated plasma tissue plasminogen activator and anti-thp-1 antibodies are independently associated with decreased graft survival in cardiac transplant recipients. Am J Cardiol 88(1):30-34

30. Wernovsky G (2008) The paradigm shift toward surgical intervention for neonates with hypoplastic left heart syndrome. Arch Pediatr Adolesc Med 162(9):849-854

31. Wernovsky G, Ghanayem N, Ohye RG, Bacha EA, Jacobs JP, Gaynor JW, Tabbutt S (2007) Hypoplastic left heart syndrome: consensus, controversies in 2007. Cardiol Young 17(suppl 2): 75-86 